\title{
DETERMINATION OF BENZODIAZEPINES IN URINE VIA BENZOPHENONE DERIVATIVES USING LIQUID CHROMATOGRAPHY-TANDEM MASS SPECTROMETRY
}

\author{
Robert ROŠKAR and Marija SOLLNER DOLENC \\ Faculty of Pharmacy, University of Ljubljana, Ljubljana, Slovenia
}

Received in July 2010

Accepted in October 2010

\begin{abstract}
The aim of this study was to validate a new method for determining benzodiazepines in urine via their benzophenone derivatives, based on liquid chromatography-tandem mass spectrometry (LC-MS/MS). Selected benzodiazepines were analysed after acid hydrolysis of urine and extraction by ethyl acetate in the presence of an internal standard. Samples were analysed using electrospray ionization LC-MS/MS in a multiple reaction monitoring mode. The chromatographic run time on a reversed phase $\mathrm{C}_{18}$ analytical column was set for $9 \mathrm{~min}$. This method was validated in 21 patients receiving methadone. Benzodiazepines intake was established in two out of three patients. LC-MS/MS results were also compared with the rapid immunoassay and the methods showed good agreement. However, in three cases benzodiazepines were detected by LC-MS/MS, but not by the immunoassay. The sensitivity of the developed LC-MS/MS method is comparable to or even higher than of previously reported methods, which makes it suitable as a confirmatory method.
\end{abstract}

KEY WORDS: benzodiazepine metabolites, diazepam, drug abuse, lorazepam, methadone treatment

Benzodiazepines are the most frequently prescribed sedatives and hypnotic drugs. There is evidence that they induce dependence and can also be abused (1). Abuse of benzodiazepines is often associated with abuse of alcohol and other psychoactive substances. It is particularly widespread among heroin addicts treated with methadone (2-4). Benzodiazepines as part of a managed methadone program alleviate some of the withdrawal symptoms of treated heroin addicts such as insomnia, nausea, anxiety, and depression. Their abuse is associated mostly with the extension of mitigation of withdrawal symptoms.

Even though benzodiazepines are structurally similar, they can not be analysed as a group because there are many pharmacologically active metabolites involved (5). Analysis of benzodiazepines and their metabolites is very important for establishing abuse or poisoning. They are mainly determined in urine and less often in serum (6). The most convenient screening methods are based on the immunoassay and only positive results need to be confirmed, usually using gas chromatography or liquid chromatography coupled with mass spectrometry (5-7). These methods are not suitable for quantification in some biological samples due to the presence of their different metabolites and/or other substances in the matrix with similar properties. This is why urine samples are usually hydrolysed with glucuronidase to obtain free drugs/metabolites or with acid to yield benzophenones $(5,8)$.

As heroin addicts on methadone could be abusing one or more benzodiazepines, it is important to use 
a method that can confirm the presence of several benzodiazepines at the same time.

We have developed a liquid chromatographytandem mass spectrometry (LC-MS/MS) method that determines low levels of various benzodiazepines in urine at the same time via their products of hydrolysis, the corresponding benzophenones. The advantage is that conjugated and non-conjugated metabolites of a benzodiazepine can be determined as benzophenones. However, there have been only a few reports so far on benzodiazepine analysis via their benzophenone derivatives, and these mainly refer to GC-MS (6) or HPLC with UV detection (9).

We validated our method by analysing the following benzophenones BF-bromazepam, BF-diazepam, BFnordiazepam, BF-lorazepam and BF-clonazepam in urine. Selected benzophenones correspond to the most relevant used/abused benzodiazepines in methadone treatment. BF-nordiazepam also identifies oxazepam, which is a main metabolite of several benzodiazepines. Suitable selectivity and sufficient sensitivity of the developed method has been confirmed in real samples of addicts receiving methadone. In addition, we compared our method with the standard immunoassay.

\section{MATERIALS AND METHODS}

\section{Standards and chemicals}

Diazepam, nordiazepam, lorazepam, clonazepam, and bromazepam were a gift of the Institute of Forensic Medicine (Faculty of Medicine, University of Ljubljana, Slovenia). Benzophenone standards of these benzodiazepines were obtained by acid hydrolysis according to the procedure described by Schutz (10). Using preparative chromatography, we additionally purified the standards to $>99 \%$ chromatographic purity. The identity of the benzophenones was confirmed by NMR and MS.

Acetonitrile (Sigma-Aldrich, Germany) and ammonium acetate (Fisher Scientific, UK) were of the HPLC grade and all other chemicals of the analytical grade.

\section{Specimens}

Control urine was obtained from healthy volunteers. Test urine samples, collected from 21 patients on methadone therapy (one sample per each patient), were provided by Nova Gorica Hospital, Slovenia. Urine was collected in plastic containers and frozen at $-20{ }^{\circ} \mathrm{C}$.

\section{Urine extraction procedure}

Three millilitres of urine were filtered, centrifuged, and transferred to a flask containing $5 \mathrm{~mL}$ of concentrated hydrochloric acid and $50 \mu \mathrm{L}$ of internal standard (IS) (BF-clonazepam). The flask was immersed in an oil bath at $100^{\circ} \mathrm{C}$ for $1 \mathrm{~h}$. After cooling to room temperature, the acidity of content was adjusted to $\mathrm{pH} 9$ to $\mathrm{pH} 11$ by adding ammonia. After extraction with $10 \mathrm{~mL}$ of ethyl acetate in four steps, the organic phase was evaporated to dryness at $40{ }^{\circ} \mathrm{C}$. The residue was redissolved in $200 \mu \mathrm{L}$ of methanol/water solution $(1: 1, \mathrm{v} / \mathrm{v})$, and an aliquot of $50 \mu \mathrm{L}$ was injected into the LC-MS/MS instrument (Varian, USA).

\section{Instrumentation}

Chromatographic separation was carried out with a ProStar 210 liquid chromatograph (Varian, USA) on a Luna C18(2), $50 \mathrm{~mm}$ x $2.0 \mathrm{~mm}$ column with a guard column Luna C18(2), $4 \mathrm{~mm}$ x $2.0 \mathrm{~mm}$ (Phenomenex, USA), both thermostated at $50{ }^{\circ} \mathrm{C}$. The injection volume was $50 \mu \mathrm{L}$. The initial mobile phase was $65 \% 5 \mathrm{mmol} \mathrm{L}^{-1}$ ammonium acetate (adjusted to $\mathrm{pH} 3.8$ with acetic acid) (A) and $35 \%$ acetonitrile (B). Gradient from $65 \% \mathrm{~A}$ to $20 \% \mathrm{~A}$ in $7.5 \mathrm{~min}$ at $0.4 \mathrm{~mL} \mathrm{~min}^{-1}$ flow rate was used. The system was then re-equilibrated at the initial condition for $1.5 \mathrm{~min}$ at a flow of $0.7 \mathrm{~mL} \mathrm{~min}^{-1}$. The total run time was $9 \mathrm{~min}$.

The ProStar 210 liquid chromatograph was coupled to a mass spectrometer. The benzophenones were detected with a triple quadrupole 1200L MS/MS (Varian, USA) in a positive electrospray ionization mode. The pressure of the drying gas (nitrogen) was set to $150 \mathrm{kPa}$ and the temperature to $350^{\circ} \mathrm{C}$. The collision gas (argon) pressure was $0.200 \mathrm{kPa}$. Capillary, detector, and other voltages were all optimised to give maximal signal for the benzophenones. Data were recorded in the multiple reaction monitoring (MRM) mode (Table 1$)$. Quadrupoles Q1 and Q3 were set at one and two unit mass resolution, respectively. Instrument control, data acquisition, and quantification were performed with a Varian MS Workstation, Ver. 6.5.

The MS/MS was protected from sample contamination with a flow-diverter valve, which was programmed to allow the flow from the column to 
Table 1 Detection of benzodiazepines in urine via benzophenones and MRM transitions for the detection of benzophenones by $L C-M S / M S$

\begin{tabular}{llcc}
\hline \multirow{2}{*}{ Benzophenone } & $\begin{array}{l}\text { Detection of different benzodiazepines } \\
\text { via the same benzophenone }\end{array}$ & $\begin{array}{c}\text { MRM transition } \\
(\boldsymbol{m} / \mathbf{z})\end{array}$ & $\begin{array}{c}\text { Collision energy } \\
/ \mathbf{e V}\end{array}$ \\
\hline \multirow{2}{*}{ BF-diazepam } & diazepam, temazepam, camazepam & $\underline{228 \rightarrow 193}$ & -10 \\
\hline \multirow{2}{*}{ BF-nordiazepam } & $\begin{array}{l}\text { diazepam, nordiazepam, oxazepam, } \\
\text { medazepam, clorazepate, prazepam, } \\
\text { pinazepam, temazepam chordiazepoxide }\end{array}$ & $\underline{232 \rightarrow 154}$ & -14 \\
\hline \multirow{2}{*}{ BF-lorazepam } & lorazepam & $\underline{232 \rightarrow 126}$ & -8 \\
\hline \multirow{2}{*}{ BF-bromazepam } & bromazepam & $\underline{266 \rightarrow 154}$ & -22 \\
\hline \multirow{2}{*}{ BF-clonazepam } & clonazepam & $\underline{277 \rightarrow 106}$ & -22 \\
\hline
\end{tabular}

MRM: multiple reaction monitoring; the transition for quantification is underlined

the MS/MS only between $2.5 \mathrm{~min}$ and $7.7 \mathrm{~min}$. At all other times the flow was diverted to waste, and $50 \%$ acetonitrile was delivered to the MS/MS by an infusion pump (Harvard 11+, Harvard Apparatus, USA) at $0.05 \mathrm{~mL} \mathrm{~min}^{-1}$.

\section{Method validation}

The specificity of the method was determined by analysing urine samples of six healthy control subjects. The presence or absence of interfering peaks at the retention times of benzophenones was determined. Standard calibration curves were constructed to ensure linearity of the instrument response. After filtration and centrifugation, control urine was spiked with standard solutions of each benzophenone to give final concentrations of $5 \mu \mathrm{g} \mathrm{L}^{-1}, 10 \mu \mathrm{g} \mathrm{L}^{-1}, 25 \mu \mathrm{g} \mathrm{L}^{-1}$, $50 \mu \mathrm{g} \mathrm{L}^{-1}, 100 \mu \mathrm{g} \mathrm{L}^{-1}, 250 \mu \mathrm{g} \mathrm{L}^{-1}$, and $500 \mu \mathrm{g} \mathrm{L}^{-1}$. The limit of detection was determined based on signalto-noise ratio $(\mathrm{S} / \mathrm{N})$ of 3 . The limit of quantification was determined as the lowest concentration on the calibration curve that exhibited acceptable accuracy (deviation less than $\pm 20 \%$ ). Accuracy was determined by comparing concentrations calculated from the calibration curve with known concentrations of spiked urine samples. Precision (CV/ \%) and accuracy (bias $/ \%$ ) were also determined at different concentration levels on standard solutions of benzophenones $(\mathrm{n}=6)$. Recovery was determined at $100 \mu \mathrm{g} \mathrm{L}^{-1}$ and $250 \mu \mathrm{g} \mathrm{L}^{-1}(\mathrm{n}=6)$ based on comparison of the peak areas of extracted samples with those of non-extracted solutions of benzophenones prepared in the reconstitution solvent with the same amount as in the spiked urine samples. Matrix effect was evaluated by comparing benzophenone responses from the spike-after-extraction samples with neat standard at the same concentration $\left(250 \mu \mathrm{g} \mathrm{L}^{-1}\right)$. Stability was determined by comparing concentrations found in two spiked urine samples $\left(100 \mu \mathrm{g} \mathrm{L}^{-1}\right.$ and $\left.250 \mu \mathrm{g} \mathrm{L}^{-1}\right)$ left in the thermostated autosampler at $4^{\circ} \mathrm{C}$ for $12 \mathrm{~h}$ to the nominal values at $0 \mathrm{~h}$.

\section{Immunoassay}

Urine samples of patients on methadone treatment were analysed using the Syva ${ }^{\mathbb{R}}$ RapidTest d.a.u. ${ }^{\circledR} \mathrm{BZO}$ (Syva Company, USA) with a cutoff of $300 \mathrm{ng} \mathrm{mL}^{-1}$ of oxazepam.

\section{RESULTS AND DISCUSSION}

\section{Method validation}

The specificity of the LC-MS/MS method was confirmed by the absence of peaks at benzophenone retention times in blank urine samples from control subjects (Figure 1). Figure 2 shows good resolution between the analytes in a spiked blank sample and no interference by any extractible endogenous material present in urine. Table 1 shows the specificity of the method through second MRM transition for each analyte.

Calibration curves were prepared with blank urine at concentrations ranging from $5 \mu \mathrm{g} \mathrm{L}^{-1}$ to $500 \mu \mathrm{g} \mathrm{L}^{-1}$ for all benzophenones. They were all linear in that range, with determination coefficient $\left(\mathrm{R}^{2}\right)$ of 0.9989 for BF-diazepam, 0.9990 for BF-nordiazepam, 0.9991 for BF-lorazepam, and 0.9981 for BF-bromazepam. 


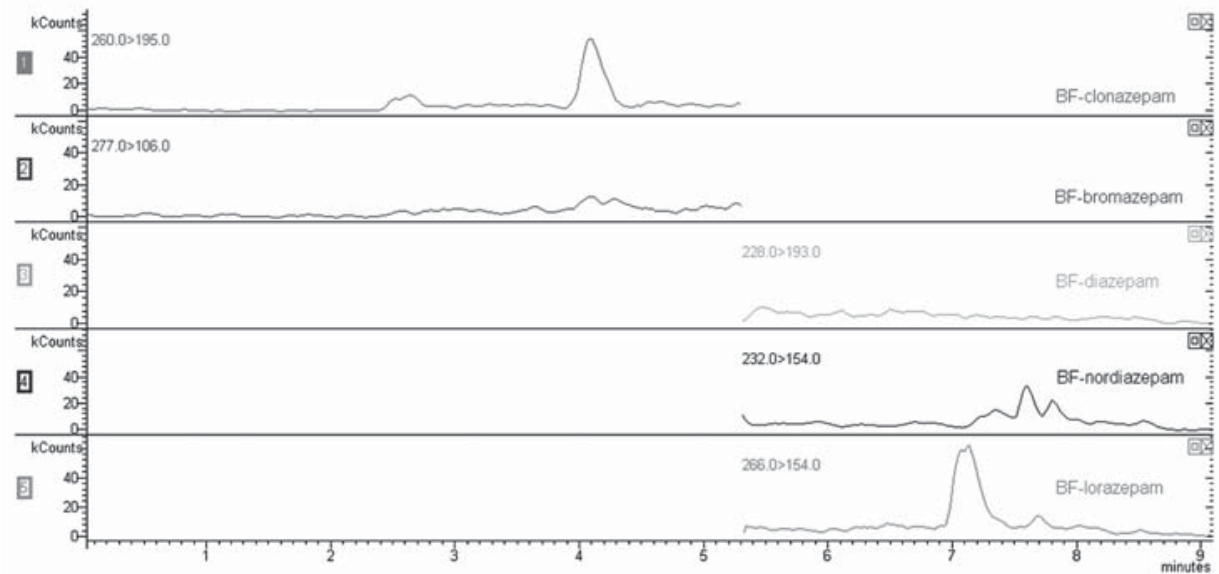

Figure 1 Chromatogram of blank urine sample from a healthy volunteer

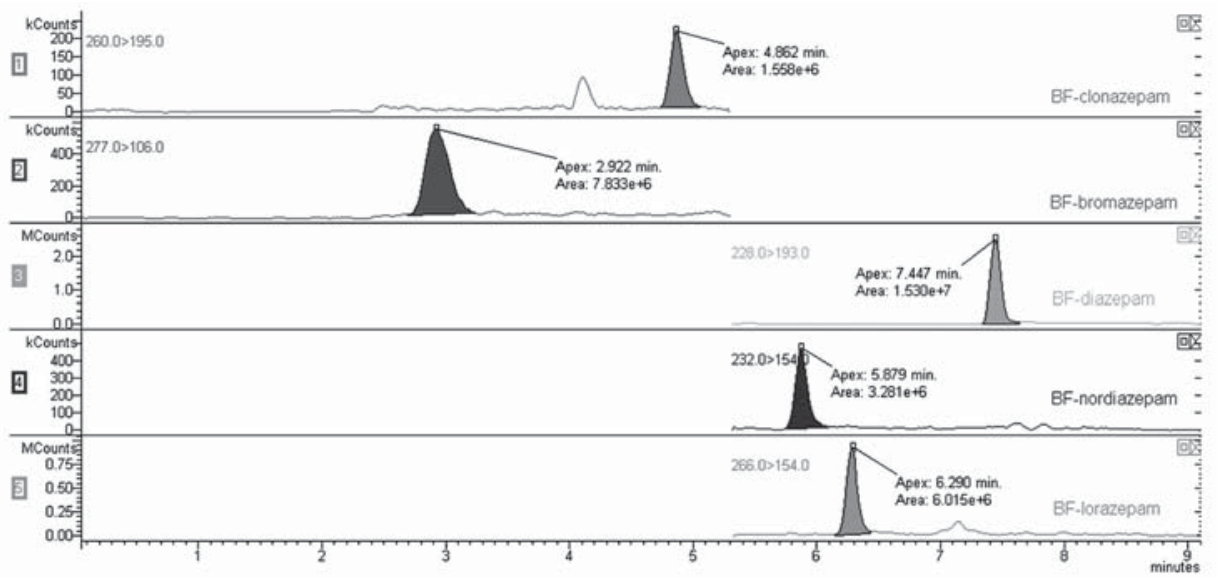

Figure 2 Chromatogram of a urine sample from a healthy volunteer spiked with benzophenone standards (100 $\left.\mu g L^{-1}\right)$

The limit of detection for the benzophenones ranged from $0.5 \mu \mathrm{g} \mathrm{L} \mathrm{L}^{-1}$ to $1 \mu \mathrm{g} \mathrm{L}-1$. Limit of quantification was set to the lowest point in the calibration curve to meet the acceptable criteria (accuracy bias $<20 \%$ ), except for BF-nordiazepam where the value was $10 \mu \mathrm{g} \mathrm{L}-1$ (Table 2).

Repeatability of the method was not established in urine samples but in standard benzophenone solutions, because of the small extract volume. Precision at
$10 \mu \mathrm{g} \mathrm{L}^{-1}$ was better than $7.2 \%$ and accuracy better than $13.5 \%$ in all cases. At higher concentrations, both parameters were even better (Table 3).

Extraction recoveries, measured at two concentrations, were consistent $(\mathrm{CV}<12 \%)$ and greater than $78 \%$ for all analytes (Table 4 ). This makes the method suitable for screening. The matrix effect of benzophenones, which also includes IS, was within the acceptable limits (93\% to $98 \%$ ) and thus

Table 2 Limits of detection and quantification (LOD and LOQ) of benzophenones in urine by LC-MS/MS ( $n=6)$

\begin{tabular}{lccc}
\hline Benzophenone & LOD $/ \boldsymbol{\mu g} \mathbf{~ L}^{-1}$ & $\mathbf{L O Q} / \boldsymbol{\mu g} \mathbf{~ L}^{-1}$ & Accuracy / \% \\
\hline BF-diazepam & 0.5 & 5 & 12.4 \\
BF-nordiazepam & 1.0 & 10 & 17.5 \\
BF-lorazepam & 1.0 & 5 & 19.6 \\
BF-bromazepam & 0.5 & 5 & 9.7 \\
\hline
\end{tabular}


Table 3 Precision (repeatability) and accuracy of benzophenones in standard solutions by LC-MS/MS ( $n=6)$.

\begin{tabular}{|c|c|c|c|c|c|c|}
\hline \multirow{2}{*}{ Benzophenone } & \multicolumn{2}{|c|}{$10 \mu \mathrm{g} \mathrm{L}^{-1}$} & \multicolumn{2}{|c|}{$100 \mu g \mathrm{~L}^{-1}$} & \multicolumn{2}{|c|}{$250 \mu \mathrm{g} \mathrm{L}^{-1}$} \\
\hline & $\mathrm{CV} / \%$ & Bias / \% & $\mathrm{CV} / \%$ & Bias / \% & $\mathrm{CV} / \%$ & Bias / \% \\
\hline BF-diazepam & 4.9 & -10.8 & 3.9 & 2.9 & 2.2 & 0.9 \\
\hline BF-nordiazepam & 6.1 & 13.5 & 1.4 & 5.0 & 1.2 & 1.2 \\
\hline BF-lorazepam & 7.2 & -5.4 & 3.9 & 3.3 & 2.9 & 0.6 \\
\hline BF-bromazepam & 3.8 & -8.9 & 4.5 & -1.8 & 3.9 & 1.2 \\
\hline
\end{tabular}

$C V$ : coefficient of variance (precision)

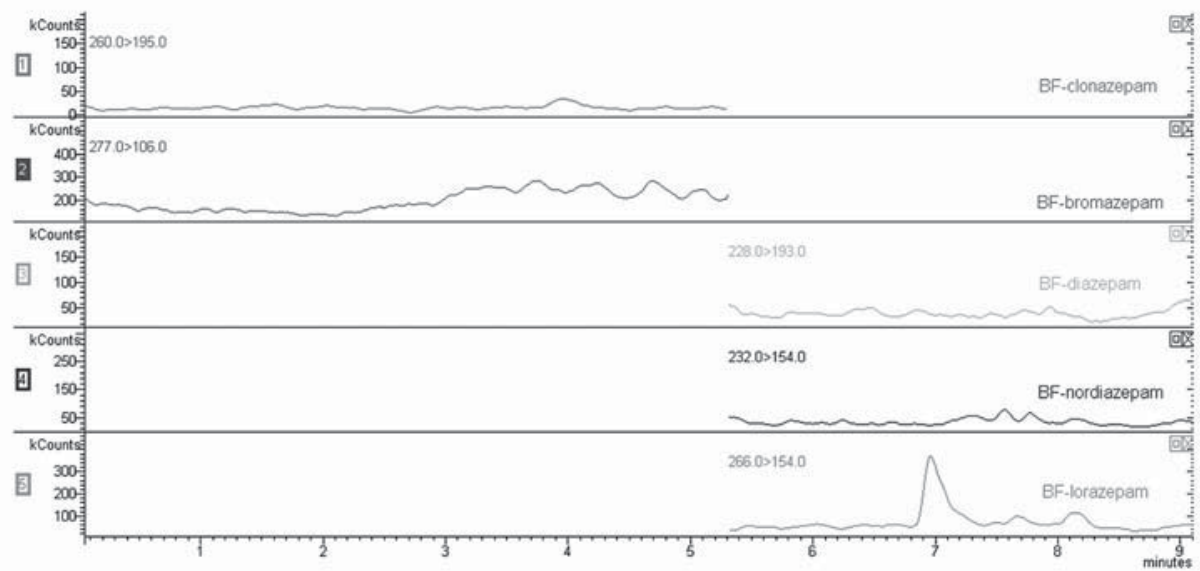

Figure 3 Chromatogram of a negative urine sample from a patient on methadone treatment

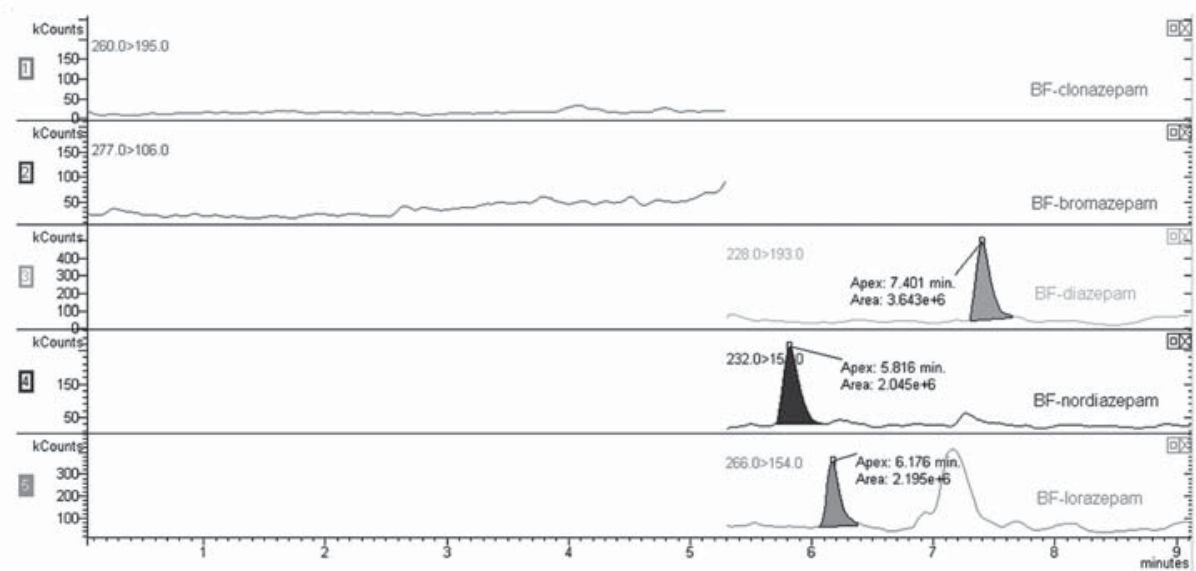

Figure 4 Chromatogram of a positive urine sample from a patient on methadone treatment; it shows the peaks of the benzophenones of nordiazepam, diazepam and lorazepam

ion suppression from the urine matrix was negligible for this method.

Stability evaluation of prepared spiked urine samples showed that the analytes were stable under storage conditions. The concentrations for all benzophenones ranged from $95.6 \%$ to $105.6 \%$.

Choosing appropriate IS is important for achieving acceptable method performance, especially with LCMS/MS. Use of deuterated IS is highly recommended since matrix effect should not affect the relative efficiency of the ionisation of the analyte and IS. We used structurally similar BF-clonazepam as IS because benzophenones are not commercially available as deuterated IS. Clonazepam is highly metabolised in vivo (ca. $99 \%$ ) and the endogenous content of BFclonazepam is very low, which renders error negligible, because IS is used at a high concentration. 
Table 4 Recovery of benzophenones from urine samples at two concentrations $(n=6)$.

\begin{tabular}{lcccc}
\hline \multirow{2}{*}{ Benzophenone } & \multicolumn{2}{c}{ Recovery / \% } & \multicolumn{2}{c}{$\mathbf{C V} / \mathbf{\%}$} \\
\cline { 2 - 5 } & $\mathbf{1 0 0} \boldsymbol{\mu g} \mathbf{~ L}^{-\mathbf{1}}$ & $\mathbf{2 5 0} \boldsymbol{\mu} \mathbf{g ~ \mathbf { L } ^ { - 1 }}$ & $\mathbf{1 0 0} \boldsymbol{\mu g} \mathbf{~ L}^{-\mathbf{1}}$ & $\mathbf{2 5 0} \boldsymbol{\mu} \mathbf{g} \mathbf{L}^{-\mathbf{1}}$ \\
\hline BF-diazepam & 85.2 & 78.1 & 6.7 & 4.4 \\
BF-nordiazepam & 87.6 & 96.1 & 8.8 & 11.8 \\
BF-lorazepam & 85.7 & 89.2 & 7.4 & 2.2 \\
BF-bromazepam & 83.6 & 83.2 & 7.1 & 4.2 \\
BF-clonazepam (IS) & 86.9 & 85.6 & 6.5 & 5.3 \\
\hline
\end{tabular}

$C V$ : coefficient of variance (precision)

\section{Determination of benzophenones in addicts on methadone treatment}

Twenty-one urine samples of patients on methadone therapy were analysed for the presence of benzophenones. Chromatograms of negative and positive urine samples are shown in Figures 3 and 4, respectively. Fourteen samples were positive for both BF-diazepam and BF-nordiazepam. This indicates that diazepam has been taken, since nordiazepam is a metabolite of diazepam. A third benzophenone, BFlorazepam, was found with the other two in only one sample. These results confirm that benzodiazepines are often co-administered to patients on methadone therapy, especially diazepam which was taken in two thirds of the studied cases. Unfortunately, we could not access medical records of patients who provided urine samples to compare reported benzodiazepine prescriptions and our findings. Even so, our findings are in line with published data on heroin addicts on methadone treatment. Detection of an additional benzodiazepine (lorazepam) makes our approach even more valuable compared to immunoassay, because it not only confirmed prescribed benzodiazepine, but also indicated to potential abuse of other benzodiazepines.

To verify the efficiency of our method we also tested the 21 urine samples for benzodiazepines using the rapid immunoassay. Twelve turned out positive, of which 11 matched the LC-MS/MS findings. The LC-MS method thus confirmed the great majority of the positive immunoassay results, with an additional three samples that were negative by immunoassay due its higher limit of detection. In fact, the sensitivity of our LC-MS/MS method for determination of benzodiazepines via benzophenones is comparable to GC-MS (6) and much higher than HPLC with UV detection (9). All this makes it a suitable confirmatory method for benzodiazepine abusers.

\section{CONCLUSION}

In current practice, urine samples are screened by the immunoassay, which is fast and convenient, and only positive results require confirmation. Benzodiazepines or their main metabolites are routinely determined in urine $(7,11,12)$. To confirm benzodiazepines in urine, we have adopted an alternative approach via benzophenones. Under the conditions of acid hydrolysis of the diazepine ring to the corresponding benzophenone, it is possible that two or more different benzodiazepines could form the same benzophenone. This reduces the specificity of the method, but the overall sensitivity is increased, since all benzodiazepine metabolites (conjugated or non-conjugated) in urine are converted to the same benzophenone. Our method detects the most relevant benzodiazepines used or abused in methadone treatment (Table 1). However, it does not detect newer benzodiazepines such as alprazolam, as they do not hydrolyse to benzophenones.

Our LC-MS/MS method is flexible and can be used to detect other compounds such as methadone or heroin. This kind of versatility, selectivity, and sensitivity will definitely secure its place in laboratory practice.

\section{Acknowledgement}

The authors wish to thank Professor Roger Pain for critical reading of the manuscript.

\section{REFERENCES}

1. Lader M. Anxiolytic drugs: dependence, addiction and abuse. Eur Neuropsychopharmacol 1994;4:85-91.

2. Lavie E, Fatséas M, Denis C, Auriacombe M. Benzodiazepine use among opiate-dependent subjects in buprenorphine maintenance treatment: Correlates of use, abuse and dependence. Drug Alcohol Depend 2009;99:338-44. 
3. Barnas C, Rossmann M, Roessler H, Reimer Y, Fleischhacker WW. Benzodiazepines and other psychotropic-drugs abused by patients in a methadone-maintence program-familiarity and preference. J Clin Psychopharmacol 1992;12:397-402.

4. Bramness JG, Kornør H. Benzodiazepine prescription for patients in opioide maintence treatment in Norway. Drug Alcohol Depend 2007;90:203-9.

5. Gambart D, Cárdenas S, Gallego M, Valcárcel M. An automated screening system for benzodiazepines in human urine. Anal Chim Acta 1998;366:93-102.

6. Cárdenas S, Gallego M, Valcárcel M. Gas chromatographicmass spectrometric confirmation of selected benzophenones from benzodiazepines in human urine following automatic screening. J Chromatogr A 1998;823:389-99.

7. Drummer OH. Methods for the measurement of benzodiazepines in biological samples. J Chromatogr B Biomed Sci Appl 1998;713:201-25.
8. Beck O, Lafolie P, Odelius G, Boreus LO. Immunological screening of benzodiazepines in urine: improved detection of oxazepam intake. Toxicol Lett 1990;52:7-14.

9. Violon C, Pessemier L, Vercruysse A. High-performance liquid chromatography of benzophenone derivates for the determination of benzodiazepines in clinical emergencies. $\mathbf{J}$ Chromatogr 1982;236:157-68.

10. Schutz H. Benzodiazepines: A Handbook. Heidelberg: Springer-Verlag; 1982.

11. Cheze M, Villain M, Pepin G. Determination of bromazepam, clonazepam and metabolites after a single intake in urine and hair by LC-MS/MS. Application to forensic cases of drug facilitated crimes. Forensic Sci Int 2004;145:123-30.

12. Borrey D, Meyer E, Lambert W, Van Peteghem C, De Leenheer AP. Simultaneous determination of fifteen lowdosed benzodiazepines in human urine by solid-phase extraction and gas chromatography-mass spectrometry. J Chromatogr B Biomed Sci Appl 2001;765:187-97. 


\section{Izvleček}

\section{DOLOČANJE BENZODIAZEPINOV V URINU PREKO BENZOFENONSKIH DERIVATOV Z UPORABO TEKOČINSKE KROMATOGRAFIJE SKLOPLJENE S TANDEMSKO MASNO SPEKTROMETRIJO}

Razvili smo selektivno in občutljivo metodo za določanje nekaterih benzodiazepinov v urinu preko določanja njihovih benzofenonov. Metoda temelji na tekočinski kromatografiji, sklopljeni s tandemsko masno spektrometrijo (LC-MS/MS). Izbrane benzodiazepine smo analizirali po kisli hidrolizi urinskih vzorcev in ekstrakciji z etilacetatom v prisotnosti internega standarda. Vzorce smo analizirali z elektrorazprševalno ionizacijo z MRM načinom detekcije. Čas kromatografske ločbe na reverznofazni $\left(\mathrm{C}_{18}\right)$ analitski koloni je bil 9 min.

Metoda je bila validirana in preizkušena na 21 pacientih, ki so prejemali metadonsko terapijo. Pri dveh tretjinah primerov je bil vnos benzodiazepinov tudi potrjen. Vzorce smo testirali tudi s hitro imunokemijsko metodo in rezultate primerjali $\mathrm{z}$ rezultati pridobljenimi z LC-MS/MS metodo. Ugotovili smo dobro ujemanje med rezultati pridobljenimi z obema metodama. Kljub temu smo $\mathrm{v}$ treh primerih določili prisotnost benzodiazepinov z LC-MS/MS metodo, ki je z imunokemijsko metodo nismo. Občutljivost razvite metode je primerljiva ali celo boljša od predhodno opisanih metod, zato jo lahko uporabimo kot potrditveno metodo.

KLJUČNE BESEDE: diazepam, lorazepam, presnovki benzodiazepinov, metadonska terapija, zloraba zdravil

\section{CORRESPONDING AUTHOR:}

Marija Sollner Dolenc

Faculty of Pharmacy, University of Ljubljana

Aškerčeva 7, SI-1000 Ljubljana, Slovenia

E-mail: marija.sollner@ffa.uni-lj.si 